\title{
Awareness as a Foundation for Developing Effective Spatial Data Infrastructures
}

\author{
Christian CLAUSEN, Denmark, Abbas RAJABIFARD, Australia, \\ Stig ENEMARK, Denmark, and Ian WILLIAMSON, Australia
}

Key words: awareness, spatial data infrastructure, inter-organizational, collaboration, cooperation

\section{SUMMARY}

The development of an effective spatial data infrastructure (SDI) often occurs in a fragmented organizational environment requiring a high level of inter-organizational collaboration. Different organizations from various jurisdictions needs to work together closely when agreeing on how they will jointly register, store, use and share data and how they will make their data available to the wider society. This collaboration is generally regarded as very difficult. In particular, organizational issues are considered one of the key fundamental constraints to inter-organizational sharing of spatial data. But what makes collaboration effective and successful? For example people often resist sharing data across organizational boundaries due to loss of control, power and independency.

In the spatial community, the term awareness is often used when discussing issues concerned with inter-organizational collaboration. However, a major problem by using the term awareness in discussions of inter-organizational collaboration is that awareness is undefined and often misused as a term in the spatial data handling community. The (over)-use of the term awareness, without having a rigorous definition to rely upon increases the difficulty of understanding and developing collaboration issues. The difficulty in quantifying and describing issues in collaboration make the development of effective spatial data infrastructures problematic since this development should be based on a conceptual framework that clearly addresses the problems spatial organizations currently encounter.

As a result, the focus of this paper is on the nature and role of awareness. It explores why and how awareness plays a fundamental role in overcoming organizational constraints and in developing collaboration between organizations. The paper discusses the concept of awareness in the area of organizational collaboration in the spatial community, explains the important role awareness plays in the development of spatial data infrastructures, and introduces a methodology to promote awareness. Furthermore, the paper aims to make people in the community more aware of the use of the term "awareness" - when to use it, how to use it and especially important, how not to use it. The paper will use land administration systems as the discipline for investigating awareness. 


\title{
Awareness as a Foundation for Developing Effective Spatial Data Infrastructures
}

\author{
Christian CLAUSEN, Denmark, Abbas RAJABIFARD, Australia, \\ Stig ENEMARK, Denmark, and Ian WILLIAMSON, Australia
}

\section{INTRODUCTION}

Awareness is today's catchword when it comes to spatial data handling. The term is widely used in the scientific literature (Craig 1995;Masser 1998;Rajabifard 2003;Van Loenen 2006; Williamson 2003) and an investigation on how often the words "awareness" and "spatial data" occur on the same webpage comes up with more than 357,000 hits (www.google.com, $16^{\text {th }}$ of March 2006).

When people in the spatial community are addressing awareness, this happens generally at two levels: Firstly, when people are discussing the importance of one organization's awareness of another organization in order to develop effective, collaborative relationships. Secondly, when people are discussing the importance of developing awareness within the community and in the wider society for the potential social opportunities that exist in the spatial information technologies that the organizations possess. The remainder of the paper addresses the first kind of awareness as internal awareness, while the second kind will be called external awareness.

A major problem by using the term awareness in discussions of inter-organizational collaboration and technology possibilities is that awareness is undefined and often misused as a term in the spatial data handling community. The (over)-use of the term awareness, without having a rigorous definition to rely upon, increases the difficulty of understanding and developing collaboration issues. The difficulty in quantifying and describing issues in collaboration make the development of effective spatial data infrastructures difficult since this development should be based on a useful conceptual framework that clearly addresses the problems spatial organizations currently encounter.

As a result, the focus of this paper is on the nature and role of awareness. It explores why and how awareness plays a fundamental role in overcoming organizational constraints and in developing collaboration between organizations. The paper discusses the concept of awareness in the area of organizational collaboration in the spatial community, explains the important role awareness plays in the development of spatial data infrastructures, and introduces a methodology to promote awareness. Furthermore, the paper aims to make people in the community more aware of the use of the term "awareness" - when to use it, how to use it and especially important, how not to use it. The paper will use land administration systems as the discipline for investigating awareness. 


\section{TOWARDS MULTI-PURPOSE LAND ADMINISTRATION SYSTEMS}

To understand the importance of awareness it is important first to understand the challenges organizations handling spatial information are facing today.

During the last two decades organizations, especially in the public land administration systems have moved from a single-purpose perspective to a multi-purpose perspective. Instead of focusing just on a specific function in the administration of land, organizations are now also focusing on making spatial information, expertise and services available to other governmental organizations and to the wider society. Drivers, such as demands for economical efficiency, minimization of data duplication, need for cross-governmental data analysis, increasing technological possibilities, and recognition of spatial information as a driver for private business and as a support for sustainable development support this development. This mean that there exist a rising political demand for an increased sharing of spatial information throughout the public sector and for deliverance of spatial information to the private sector.

The goal of multi-purpose organizations is an effective handling of land information data in and between the organizations through efficient and effective spatial data infrastructures (SDIs). Structures that allow easy access, smooth sharing and seamless integration of data, both internally in the organizations and externally to other governmental institutions, private branches and ordinary citizens. SDI is thus generally understood to be "a framework continuously facilitating the efficient and effective generation, dissemination, and use of needed spatial information within a community or between communities” (Van Loenen 2006).

However, the organizational framework that many public organizations are facing often has a structure that complicates the development of efficient and effective SDIs. Due to historical reasons land administration systems typically consist of multiple different governmental organizations located in different ministries. This fragmentized structure gives rise to issues concerning inter-organizational collaboration, which are critical to the function of the systems. Research on data sharing demonstrates that institutional issues often are the most important factor when it comes to developing efficient and effective SDIs (Onsrud and Rushton 1995). This means that the effect of SDIs in land administration systems to support the development of multi-purpose systems is highly reliant on collaboration and mutual understanding among the organizations in the systems. Furthermore, the organizations must develop a high knowledge of their changing role in society and on how the organizations only together can full fill the changing demands that land administration systems are foreseeing.

Increased exchange of property related geographic information to public and private actors in society requires more integrated management of the future development of land administration systems. Stakeholders in land administration systems must agree on how in the future they will register data, store data, and share data both internally and externally, to fulfill the increased demands from other governmental institutions and the wider society. Is this development evident today? Are the separated organizations within land administration systems changing their focus from data handling in isolated organizations, fulfilling sharply outlined tasks - silo

TS 62 - SIM - Policy and Strategy $3 / 15$

Christian Clausen, Abbas Rajabifard, Stig Enemark and Ian Williamson

Awareness as a Foundation for Developing Efficient Spatial Data Infrastructures

Shaping the Change

XXIII FIG Congress

Munich, Germany, October 8-13, 2006 
thinking, to service orientated, modern organizations that deliver land information to wider society in close contact with other governmental organization? Generally not!

Take for instance an example from the cadastral system in Demark. Denmark has a cadastral system that fully complies with the demands of a modern cadastral system in terms of the traditional tenure security, land trading and developing functions (for a reference on the function of the Danish land administration system see Enemark et al. (2002)). The cadastral system - the Land Register and the cadastral mapping agency, due to historical reasons are located in two different ministries. They have in general a different view on the importance of spatial data in wider society. They do not seem to share the visions of the future multi-purpose system and they disagree on how crucial the data that the two organizations posses are to society. The system is currently securing tenure and supporting the trading of land in society in a very efficient manner. However, when it comes to building an up-to-date spatial data infrastructure that support the wider societies need of land information, the potential is imperfect. Partly due to insufficient relations caused by a historical fragmentation but also due to a lack of common recognition on the two organization's role in the future multi-purpose land administration system. The same problems exist in other countries around the world.

\section{GENERAL DEFINITIONS AND MODELS ON AWARENESS}

The above sections argue that increased collaboration is essential for the future development of land administration systems. As mentioned, many authors (Craig 1995;Masser 1998;Rajabifard 2003;Van Loenen 2006;Williamson 2003) in the field of spatial information handling have pointed out that awareness is fundamental when organizations develop collaborative relationships and are sharing data with the wider society. However, the term awareness has been used rather uncritically, probably because of lack of definition. The big question therefore is what awareness actually means in relation to organizational collaboration and spatial data sharing? In order to answer this question, the paper will first introduce some of the general definitions and models of awareness.

On a general level the Oxford American Dictionary of Current English defines "aware” as being "conscious; not ignorant; having knowledge". The same meaning can be observed within the field of psychology's definition of awareness on the personal level. Here awareness is defined as being “... awake to reality, to recognize the situation in which one exists" (Oden 1969). Alter and Hage (1993) support the above meaning of awareness in their book "Organizations working together". Here, the authors focus on awareness between organizations and argue that awareness is the main precondition for developing collaboration among organizations in an inter-organizational network. From one organization to another there should exist awareness of other organizations needs and "a perception that they in some way are compatible with ones' own” (Alter and Hage 1993).

Hall (1996) supports Alter and Hage's definition of awareness on the inter-organizational level by defining awareness as "the recognition of other organizations and the recognition by organizational representatives that their organization is interdependent with other organizations in their field.”

TS 62 - SIM - Policy and Strategy

Christian Clausen, Abbas Rajabifard, Stig Enemark and Ian Williamson

Awareness as a Foundation for Developing Efficient Spatial Data Infrastructures

Shaping the Change

XXIII FIG Congress

Munich, Germany, October 8-13, 2006 
However, more specifically, Van de Ven and Ferry (1980) present an understanding on the importance of awareness when developing inter-organizational relationships, see figure 1 below.

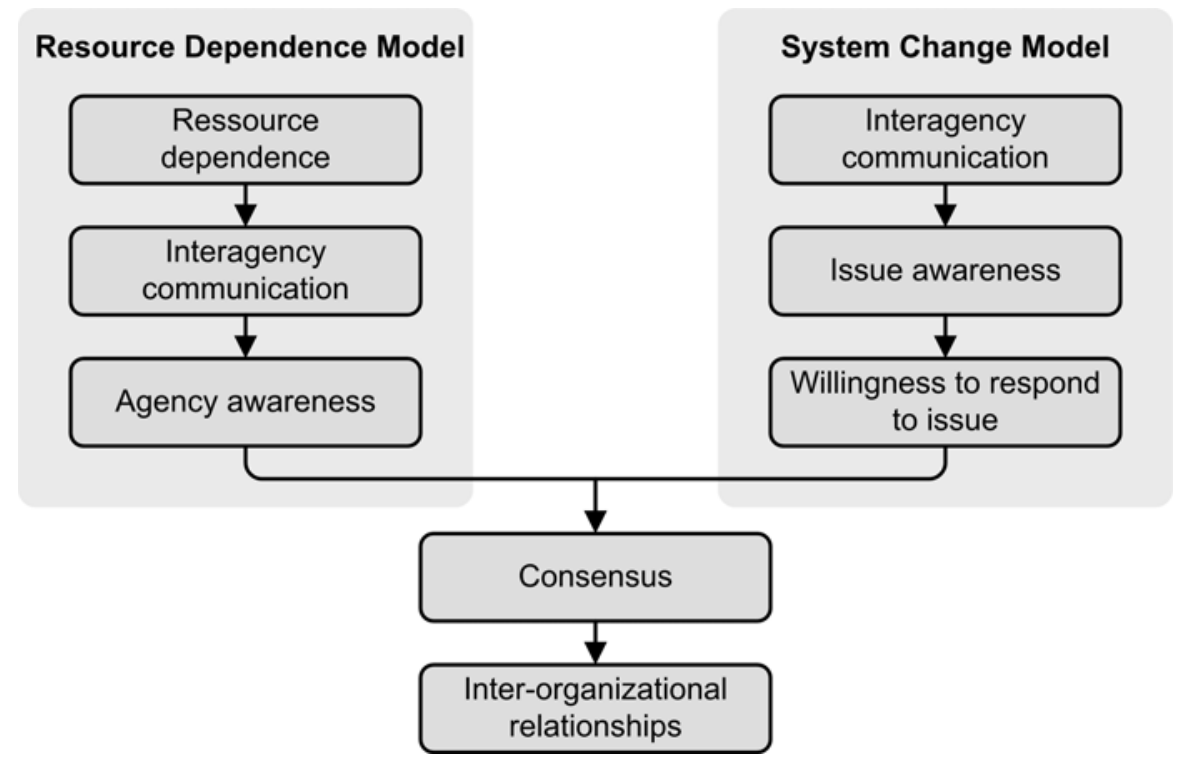

Figure 1 Awareness is important both within and between organizations, when organizational changes occur (Van de Ven and Ferry 1980)

Figure 1 displays on the left how awareness is essential in the acknowledgement of an organization's resource dependency of other organizations and on the right how awareness can lead to actual system changes towards increased organizational collaboration. The second model is of special importance here because of the focus on organizations in transition - the development from single purpose systems towards multi purpose systems.

In the resource dependency model, Van de Ven and Ferry argue that acknowledgement of resource dependency in an agency (or organization) results in interagency communication, which leads to awareness in the agency where collaboration is necessary.

To the right, the figure also displays how inter-agency communication develops awareness on a specific issue and increases the willingness in the organization to respond to this issue. Alter and Hage (1993) supports this view by arguing that awareness is central in the strengthening of inter-organizational networks in the way awareness promotes willingness to collaborate and develop trust among organizations. Alter and Hage see willingness and trust as the basic conditions for the development of inter-organizational networks because it changes the normal perceptions of cost and benefits. It requires that organizations "concerned with their own prosperity and survival, share resources and work with other organizations...” (Alter and Hage 1993). 
In summary, Van de Ven and Ferry (1980) and Alter and Hage (1993) suggest that awareness is very important to the relationship between organizations. Awareness in an interorganizational sense is about organizations having knowledge of other organizations purpose and role and on how their organization is interdependent with other organizations in their field. Furthermore, awareness is seen as fundamental to the development of organizational relationships because it affects trust between organizations, the willingness to work together, and the organizations understanding of mutual interdependency.

\section{FROM INTERNAL TO EXTERNAL AWARENESS}

While, the above explanations on awareness do provide some clarification on the term awareness and its role in inter-organizational relationships, it is clear that the existing definitions in the field of organization theory only focus on awareness between organizations internal awareness. However, it still is difficult to use awareness as an analytical tool because the above definitions only define awareness very generally.

As mentioned in the introduction, awareness generally is being used in two different ways. Firstly, when people are discussing the importance of one organization's awareness of another organization in order to develop effective, collaborative relationships. Secondly, when people are discussing the importance of developing awareness within the community and in the wider society for the potential social opportunities that exist in the spatial information technologies that the organizations possess.

However, the two different aspects of awareness, from an organizational viewpoint are highly inter-related. If public organizations are going to develop external awareness of the needs of users in the public and private sector for spatial information and services, the organizations have to develop a high degree of internal awareness of the interdependency with other organizations in order to avoid duplication of effort and improve the coverage of data and integration of services. In the discussion of awareness as a foundation for developing effective SDIs and multi purpose systems, this paper therefore suggests that the development of such systems require first development of internal awareness and then external awareness.

\section{PHASES OF AWARENESS}

As suggested, awareness can be split up in two categories: Internal - and external awareness. However, it is still possible to dig even deeper into the understanding of awareness. Awareness is closely linked to relations between organizations and literature widely acknowledge that there exist different phases of relationships. Therefore, it is suggested that these theories may be transferred to the area of awareness in order to develop an understanding of different phases of awareness.

By looking into the theories of the phases of trust (Child and Faulkner 1998) and interdependency (Azad and Wiggins 1995;Gray 1985) in the development of relationships between organizations, the authors suggest that the following phases of relations exist when organizations develop partnerships.

TS 62 - SIM - Policy and Strategy

Christian Clausen, Abbas Rajabifard, Stig Enemark and Ian Williamson

Awareness as a Foundation for Developing Efficient Spatial Data Infrastructures

Shaping the Change

XXIII FIG Congress

Munich, Germany, October 8-13, 2006 
Collaboration

Problem-setting phase

\section{Cooperation}

Direction-setting phase

Coordination

Structuring phase

Implementation

Problem-solving phase
Problem-setting is concerned with identification of the stakeholders within a domain and mutual acknowledgement of the issues that join them. The actors must agree on who has a legitimate stake in an issue and exactly what the joint issue is.

The stakeholders begin to guide their individual interests towards each other and begin to identify, appreciate and sense the common purpose they share. The stakeholders enters this phase by articulating values, goals and visions, that along the process "serve to correlate the stakeholders' activities towards mutually desirable ends” (Azad and Wiggins 1995:36).

The stakeholders begin to create the actual long lasting structures and measures that can "sustain their collective appreciation and problem-solving activities” (Gray 1985:917). To enter this phase the stakeholders must agree on the concrete problems or possibilities that exist in the domain and they must go into negotiations on building a regulative framework that is acceptable by all partners. "Specific goals are set, tasks are elaborated and roles are assigned to stakeholders” (Gray 1985:917).

The stakeholders put projects in place to solve shared interorganizational problems or develop possibilities identified by the stakeholders in common.

The stakeholders recognize the need of more permanent relations in order to maintain future relations. The outcome may be establishment of permanent committees or regular meetings with exchange of experience on partnerships.

The above phases identify how relationships between organizations are closely related to the awareness of stakeholders, common goals and problems, and the need to develop permanent structures for further relationships.

\subsection{Internal awareness}

Since it seems appropriate to use awareness as a condition for the development of organizational relationships the following matrix transforms the general concepts from the above phases of relationships into a model on stages of internal awareness. 


\begin{tabular}{|c|c|c|c|}
\hline $\begin{array}{l}\text { Overall } \\
\text { step }\end{array}$ & $\begin{array}{c}\text { Name and role of stage of } \\
\text { awareness }\end{array}$ & $\begin{array}{c}\text { Description of stage of } \\
\text { awareness } \\
\end{array}$ & $\begin{array}{c}\text { Catalyst between stage of } \\
\text { awareness } \\
\end{array}$ \\
\hline \multirow{9}{*}{ 音 } & Existence awareness & $\begin{array}{l}\text { Awareness of other organizations in } \\
\text { the inter-organizational networks }\end{array}$ & \multirow{2}{*}{$\begin{array}{l}\text { - Articulation of role } \\
\text { - Feeling of coincidence of role }\end{array}$} \\
\hline & \multirow{2}{*}{$\begin{array}{l}\text { Collaboration awareness } \\
\text { Problem-setting }\end{array}$} & \multirow{2}{*}{$\begin{array}{l}\text { Awareness of shared role of } \\
\text { organizations in the inter- } \\
\text { organizational networks }\end{array}$} & \\
\hline & & & \multirow{2}{*}{$\begin{array}{l}\text { - Articulation of role capabilities and } \\
\text { resources } \\
\text { - Feeling of need for capabilities and } \\
\text { resources }\end{array}$} \\
\hline & \multirow{6}{*}{$\begin{array}{l}\text { Cooperation awareness } \\
\text { Direction-setting }\end{array}$} & \multirow{2}{*}{$\begin{array}{l}\text { Awareness of capabilities and } \\
\text { resources in the inter-organizational } \\
\text { networks }\end{array}$} & \\
\hline & & & \multirow{2}{*}{$\begin{array}{l}\text { - Articulation of values, goals and } \\
\text { visions } \\
\text { - Feeling of coincidence of values, } \\
\text { goals and visions }\end{array}$} \\
\hline & & $\begin{array}{l}\text { Awareness of shared values, goals } \\
\text { and vision among the organizations }\end{array}$ & \\
\hline & & in the inter-organizational networks & \multirow{2}{*}{$\begin{array}{l}\text { - Articulation of need for } \\
\text { partnerships to reach shared goals } \\
\text { and visions } \\
\text { - Feeling of interdependency }\end{array}$} \\
\hline & & \multirow{2}{*}{$\begin{array}{l}\text { Awareness of need for partnerships } \\
\text { in the inter-organizational networks } \\
\text { to reach shared goals and visions }\end{array}$} & \\
\hline & & & $\begin{array}{l}\text { - Articulation of problems and/or } \\
\text { presentation of new possibilities }\end{array}$ \\
\hline \multirow{3}{*}{ 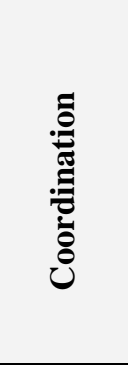 } & \multirow{2}{*}{$\begin{array}{l}\text { Coordination awareness } \\
\text { Structuring }\end{array}$} & \multirow{2}{*}{$\begin{array}{l}\text { Awareness of shared problems } \\
\text { and/or new possibilities in the inter- } \\
\text { organizational networks }\end{array}$} & $\begin{array}{l}\text { - Feeling of coincidence of problems } \\
\text { and/or common interest in new } \\
\text { possibilities }\end{array}$ \\
\hline & & & $\begin{array}{l}\text { - Articulation on how to solve } \\
\text { problems and/or develop new } \\
\text { possibilities }\end{array}$ \\
\hline & \multirow{2}{*}{$\begin{array}{l}\text { Implementation awareness } \\
\text { Problem solving }\end{array}$} & \multirow{2}{*}{$\begin{array}{l}\text { Awareness on how to solve problems } \\
\text { and develop new possibilities in the } \\
\text { inter-organizational networks }\end{array}$} & $\begin{array}{l}\text { - Agreement on plan to solve } \\
\text { problems and/or develop new } \\
\text { possibilities }\end{array}$ \\
\hline \multirow{2}{*}{$\stackrel{\mathscr{\Xi}}{\stackrel{\Xi}{\Xi}}$} & & & \multirow{2}{*}{$\begin{array}{l}\text { - Implementation of tasks in order to } \\
\text { solve problems and/or develop new } \\
\text { possibilities }\end{array}$} \\
\hline & $\begin{array}{l}\text { Evolution awareness } \\
\text { Maintaining relations }\end{array}$ & $\begin{array}{l}\text { Awareness of success and need for } \\
\text { further common projects to maintain } \\
\text { the established relations in the inter- } \\
\text { organizational networks }\end{array}$ & \\
\hline
\end{tabular}

Figure 2 Internal awareness model

Figure 2 - the internal awareness model - shows that when organizations in an interorganizational network develop collaborative relationships this ideally happens through three overall steps (see Nedovic-Budic and Pinto 1999) - a motivation step, a coordination step and a outcome step. Inter-organizational networks can be defined as "planned and managed cooperative ventures between otherwise independent agents" (Kumar and van Dissel 1996).

In the motivation step, the stakeholders are "getting to know each other". What other organizations exist in the domain and why are these organizations interesting? The organizations initially develop awareness of each other (existence awareness). Then the stakeholders develop awareness of the roles they share, e.g. as providers of cadastral information (collaboration awareness). Hereafter, the stakeholders develop firstly awareness of

Christian Clausen, Abbas Rajabifard, Stig Enemark and Ian Williamson

Awareness as a Foundation for Developing Efficient Spatial Data Infrastructures

Shaping the Change

XXIII FIG Congress

Munich, Germany, October 8-13, 2006 
each others capabilities and resources, secondly awareness of the shared values, goals and vision and thirdly awareness of the need for partnerships to reach shared goals and visions (cooperation awareness).

In the coordination step the organizations are "getting ready to work with each other". They identify common problems or possibilities that exist and how may these be solved or developed. Initially, the organizations develop awareness of the shared problems and/or new possibilities that the organizations want to deal with in common (coordination awareness). Then the organizations develop awareness of how to solve these problems (implementation awareness).

In the last step, the outcome step, the organizations have hopefully identified a solution to one or more of their common problems or developed new possibilities. The organizations are now "identifying with each other". The organizations develop awareness of success and need for further common projects to maintain the established relations (evolution awareness).

However, the stages of awareness do not evolve by themselves. The internal awareness model therefore also argues that certain catalysts must be present to evolve the degrees of awareness. Articulation is therefore an ongoing process. This term covers communication between the organizations in a broad context, both through informal and formal channels. Informal channel may be the exchange of information through reallocation of staff, discussion in crossorganizational working groups, general information gathering etc. Formal channels are coordinating bodies and coordinating meetings on the strategic levels between the organizations etc. While informal channels of information provide the foundation for developing awareness, the most important development of awareness on all levels in an organization comes from formal channels of information exchange. Coordinating bodies seem especially to play a important role in developing awareness, since they act as agents of overall exchange of views, roles and superordinate goals and visions.

While communication is fundamental in developing awareness this is only a tool. If the organizations are not serious for developing relations with other organizations, the communication is in vain. Especially in the motivation phase, where the organizations are "getting to know each other" it is crucial that the members of the organizations feel a coincidence of the role, values, goals and interdependency. A number of possible barriers affect this feeling. In the area of sharing of spatial information the amount of literature is extensive in this field (Onsrud and Rushton 1995). Besides the lack of inter-organizational communication, the motivation phase, particularly willingness (Wehn de Montalvo 2002) and trust (Pinto and Onsrud 1995) seem to be important factors. This paper will however not go further into a discussion on these barriers since the aim here is to develop a better understanding on awareness not the factors that obstruct the development of awareness. 


\subsection{External awareness}

The external awareness in the context of spatial information - is concerned with making spatial information, expertise and services available to other governmental organizations and to society in a wider context, in order to support and underpin the value of the spatial information that exist in the organizations. The below figure 3 - the external awareness model - takes an organizational viewpoint and does hence not go into how the external environment develops awareness on the information, expertise and services that the organizations posses.

\begin{tabular}{|c|c|c|c|}
\hline $\begin{array}{l}\text { Overall } \\
\text { step }\end{array}$ & $\begin{array}{c}\text { Name and role of stage of } \\
\text { awareness }\end{array}$ & $\begin{array}{c}\text { Description of stage of } \\
\text { awareness }\end{array}$ & $\begin{array}{c}\text { Catalyst between stage of } \\
\text { awareness }\end{array}$ \\
\hline \multirow{6}{*}{. } & \multirow[t]{2}{*}{ Need defining awareness } & \multirow{2}{*}{$\begin{array}{l}\text { Awareness of society’s need and } \\
\text { interest of the spatial information, } \\
\text { expertise and services that the } \\
\text { organizations posses and/or can } \\
\text { deliver }\end{array}$} & $\begin{array}{l}\text { - External pressure from politicians, } \\
\text { community, market, institutions } \\
\text { and organizations and/or internal } \\
\text { pressure from organizations in the } \\
\text { network }\end{array}$ \\
\hline & & & \multirow{2}{*}{$\begin{array}{l}\text { - Articulation of role of inter- } \\
\text { organizational network in society } \\
\text { - Feeling of coincidence of role of } \\
\text { inter-organizational network in } \\
\text { society }\end{array}$} \\
\hline & \multirow{4}{*}{$\begin{array}{l}\text { Collaboration awareness } \\
\text { Problem-setting }\end{array}$} & \multirow{2}{*}{$\begin{array}{l}\text { Awareness of the role of the inter- } \\
\text { organizational network in society }\end{array}$} & \\
\hline & & & \multirow{2}{*}{$\begin{array}{l}\text { - Articulation of need for } \\
\text { partnerships to reach shared goals } \\
\text { and visions } \\
\text { - Feeling of interdependency }\end{array}$} \\
\hline & & \multirow{2}{*}{$\begin{array}{l}\text { Awareness of organizational } \\
\text { interdependency in order to reach } \\
\text { shared goals and visions }\end{array}$} & \\
\hline & & & \multirow{2}{*}{$\begin{array}{l}\text { - Articulation of problems and/or } \\
\text { presentation of new possibilities } \\
\text { - Coincidence of problems and/or } \\
\text { common interest in new } \\
\text { possibilities }\end{array}$} \\
\hline \multirow{3}{*}{ ن̃ } & \multirow{2}{*}{$\begin{array}{l}\text { Coordination awareness } \\
\text { Structuring }\end{array}$} & \multirow{2}{*}{$\begin{array}{l}\text { Awareness of shared problems } \\
\text { and/or new possibilities }\end{array}$} & \\
\hline & & & \multirow{2}{*}{$\begin{array}{l}\text { - Articulation on how to solve } \\
\text { problems and/or develop new } \\
\text { possibilities } \\
\text { - Agreement on plan to solve } \\
\text { problems and/or develop new } \\
\text { possibilities }\end{array}$} \\
\hline & $\begin{array}{l}\text { Implementation awareness } \\
\text { Problem solving }\end{array}$ & $\begin{array}{l}\text { Awareness on how to solve } \\
\text { problems and develop new } \\
\text { possibilities }\end{array}$ & \\
\hline 䔸 & $\begin{array}{l}\text { Evolution awareness } \\
\text { Maintaining relations }\end{array}$ & $\begin{array}{l}\text { Awareness of success and need for } \\
\text { further common projects to maintain } \\
\text { the established relations }\end{array}$ & $\begin{array}{l}\text { - Implementation of tasks in order } \\
\text { to solve problems and/or develop } \\
\text { new possibilities }\end{array}$ \\
\hline
\end{tabular}

Figure 3 External awareness model

It is clear that the models on internal and external awareness, presented in figure 2 and 3, are very much alike. However, what make the models different from each other are the motivation steps. In the model on internal awareness the motivation step focuses on building awareness between organizations to "get to know each other", the motivation phase in the external awareness model focuses on making the organizations "getting to know the others".

Christian Clausen, Abbas Rajabifard, Stig Enemark and Ian Williamson

Awareness as a Foundation for Developing Efficient Spatial Data Infrastructures

Shaping the Change

XXIII FIG Congress

Munich, Germany, October 8-13, 2006 
For organizations in land administration, the first stage of awareness is therefore on awareness of the need of the spatial information, expertise and services that the organizations posses and/or can deliver (need defining awareness). Organizations do not develop multi-purpose service-orientated land administration systems if they not are aware of a demand for their spatial information.

While awareness of the demand for information may be seen as a precondition for developing external awareness, the organizations involved in developing multi-purpose systems, e.g. the land registry and the cadastral mapping agency, still have to develop collaborative structures and policies (SDIs) for the sharing and distribution of spatial information. The next logical stage is therefore an awareness of the role that the organizations play in society and an awareness of the interdependency one organization have to other organizations that possess adjacent information. This stage is called collaboration awareness, as was the case in the model on internal awareness. The coordination and outcome steps are identical in the internal and external models on awareness and will therefore not be emphasized here.

However, what again is important are the catalysts that must be present to evolve the degrees of awareness. It can be argued, by using Wehn de Montalvo's (2002) component of social pressure for developing willingness for spatial data sharing, that external pressure from politicians, community, market, institutions and organizations and/or internal pressure from organizations in the network are the mean for developing the first crucial step of awareness on the path towards multi-purpose land administration systems. In the motivation step the next stages of awareness are driven by articulation and feelings of coincidence between the organizations, as could be seen in the model on internal awareness.

\subsection{Definitions and methodology}

By combining the findings in the development of the above two models on internal and external awareness, it is now possible to define the term awareness in context of organizational awareness in spatial community's development towards multi-purpose systems. Again it is important to remember that that the road towards multi-purpose systems demands first internal awareness and then external awareness.

Internal awareness involves the stages of recognition that allows organizations to make sound decisions in solving problems or developing solutions regarding handling of spatial information, expertise and services between the organizations.

External awareness involves the stages of recognition that makes organizations recognize why and how they alone and together can make their spatial information, expertise and services available to society in order to support social, economic and sustainable development.

Figure 4 presents below the understanding of internal awareness as an inter-organizational relationship, while external awareness is focused on the relation to the external environment. 


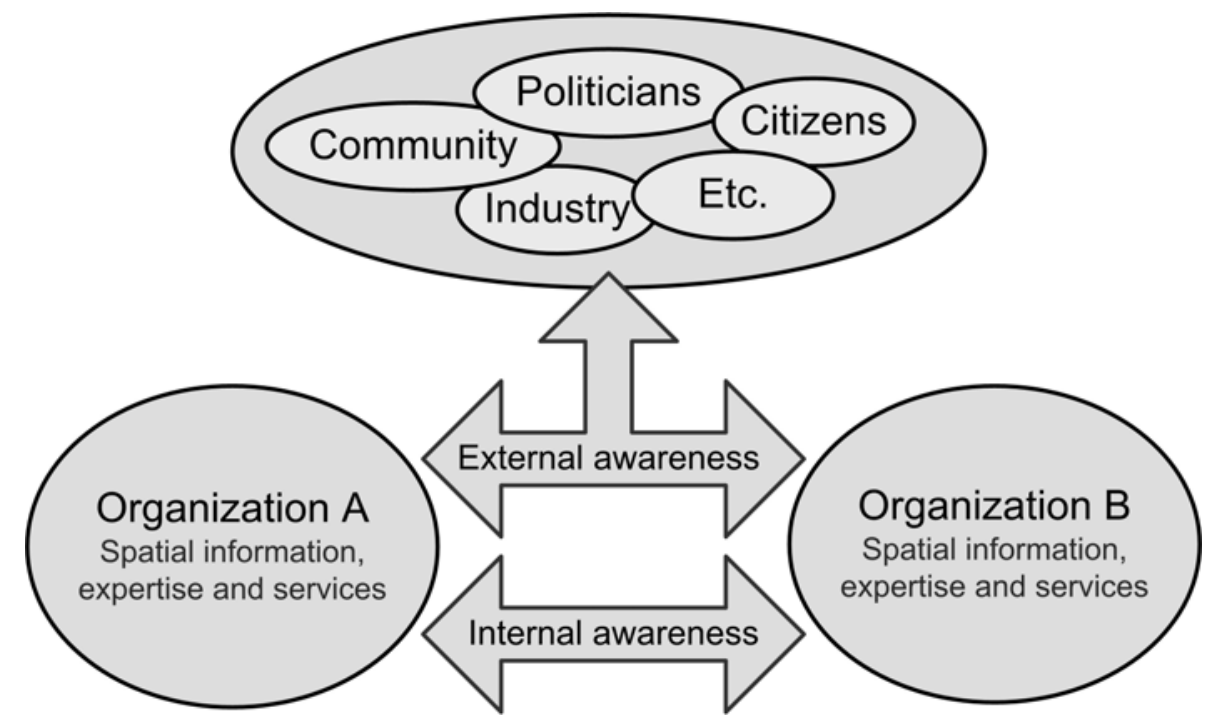

Figure 4 Internal awareness concerns inter-organizational relations, while external awareness concerns the organization's relation to the external environment

\section{USE OF THE INTERNAL AND EXTERNAL AWARENESS MODELS}

Critics might argue the stages in the above models are rather obvious, that the models just are using other words for well-known theories or that the models display a simplistic scenario of the uphill battles of developing collaborative partnerships. It can nonetheless be argued that many of the problems that exist, especially in the public sector today, in developing efficient and effective SDIs for both internal and external distribution of spatial data come from a lack of awareness, especially in the early phases of these relationships - the motivation steps. It is furthermore important to recognize the model as an ideal process that can help pinpointing problems in inter-organizational relationships, and not as an illustration of real life organizational interactions with all the struggles of control, power and independency.

An example of how to use the model can be found in the development of spatial services within public institutions. Often public institutions start developing spatial services, e.g. web services, without having built the basic internal awareness of other organizations in the interorganizational network and without having built awareness of the needs in society and the need for cross governmental partnerships to fulfil these needs - an awareness that is critical when developing external services in the context of multipurpose systems. The organizations are "silo"-minded at a time when they ought to be outreaching and co-operative.

\section{CONCLUSION}

This paper argues in the context of SDIs that awareness is critical both when organizations want to develop effective collaborative relationships and when organizations in the spatial community are developing towards multipurpose systems. However, while the term awareness is widely used in the spatial community when discussing these aspects, the term has not yet

TS 62 - SIM - Policy and Strategy

$12 / 15$

Christian Clausen, Abbas Rajabifard, Stig Enemark and Ian Williamson

Awareness as a Foundation for Developing Efficient Spatial Data Infrastructures

Shaping the Change

XXIII FIG Congress

Munich, Germany, October 8-13, 2006 
been defined in the perspective of spatial organizations, which make the use of the term awareness problematic.

Because the existing definitions on awareness only focus on inter-organizational relations, this paper has developed and discussed two models and definitions on awareness. The paper argues, through the two concepts internal - and external awareness that awareness evolves in steps, and that especially the first of these steps - the motivation step, are essential when developing inter-organizational collaboration. The paper also argues that it is essential that spatial organizations in an inter-organizational network first develop a high degree of awareness of each other before starting to develop awareness of what external services they should deliver to the wider society. First internal awareness, then external awareness.

\section{REFERENCES}

Alter, C. and J. Hage. 1993. Organizations working together. London: Sage publications. Azad, B. and L. L. Wiggins. 1995. Dynamics of inter-organizational geographic data sharing: A conceptual framework for research. In Sharing geographic information, eds. Onsrud, H. J. and G. Rushton, 22-43. (New Brunswick, New Jersey: Centre for Urban Policy Research).

Child, J. and D. Faulkner. 1998. Strategies of cooperation: Managing alliances, networks, and joint ventures. New York: Oxford University Press Inc.

Craig, W. J. 1995. Why we can't share data: Institutional inertia. In Sharing geographic information, eds. Onsrud, H. J. and G. Rushton, 107-118. (New Brunswick, New Jersey: Centre for Urban Policy Research).

Enemark, S., J. Wolters, H. Brande-Lavridsen, and S. R. Nielsen. 2002. "The Danish way." $<$ www.ddl.org/thedanishway/> Retrieved 2/9/2005.

Gray, B. 1985. Conditions facilitating interorganizational collaboration. Human Relations 38, no. 10:911-936.

Hall, R. H. 1996. Organizations, structures, processes and outcomes.: Prentice Hall.

Kumar, K. and H. G. van Dissel. 1996. Sustainable collaboration: Managing conflict and cooperation in interorganizational systems. MIS Quarterly 20, no. 3:279-300.

Masser, I. 1998. Governments and geographic information. London: Taylor \& Francis.

Nedovic-Budic, Z. and J. K. Pinto. 1999. Understanding Interorganizational GIS Activities: A Conceptual Framework . URISA Journal 11, no. 1:53-64.

Oden, T. C. 1969. The structure of awareness.: Abingdom Press.

Onsrud, H. J. and G. Rushton. 1995. Sharing geographic information. New Brunswick, New Jersey: Centre for Urban Policy Research.

Pinto, J. K. and H. J. Onsrud. 1995. Sharing geographic information across organizational boundaries: A research framework. In Sharing geographic information, eds. Onsrud, H. J. and G. Rushton, 44-64. (New Brunswick, New Jersey: Centre for Urban Policy Research).

Rajabifard, A. 2003. SDI diffusion - A regional level case with relevance to other levels. In Developing spatial data infrastructures: From concept to reality, eds. Williamson, I. P., A. Rajabifard, and M. F. Feeney, 79-94. (London: Taylor and Francis).

TS 62 - SIM - Policy and Strategy

Christian Clausen, Abbas Rajabifard, Stig Enemark and Ian Williamson

Awareness as a Foundation for Developing Efficient Spatial Data Infrastructures

Shaping the Change

XXIII FIG Congress

Munich, Germany, October 8-13, 2006 
Van de Ven, A. H. and D. L. Ferry. 1980. Measuring and assessing organizations. New York: John Wiley \& Sons.

Van Loenen, B. 2006. Developing geographic information infrastructures - The role of information policies. Delft: Delft University Press.

Wehn de Montalvo, U. 2002. Mapping the determinants of spatial data sharing. Paper presented at 8th EC-GI \& GIS Workshop, 3 2002, at Dublin, Ireland.

Williamson, I. P. 2003. SDIs - Setting the scene. In Developing spatial data infrastructures: From concept to reality, eds. Williamson, I. P., A. Rajabifard, and M. F. Feeney, 3-16. (London: Taylor and Francis).

\section{ACKNOWLEDGEMENTS}

The authors wish to gratefully acknowledge the members of the Centre for Spatial Data Infrastructures and Land Administration at the University of Melbourne, as well as the members of the Department of Development and Planning at Aalborg University for assisting and supporting the preparation of this paper and the associated research. The ideas presented in this article are a shortened version of an ongoing research project that will be published in a journal.

\section{BIOGRAPHICAL NOTES}

Christian Clausen is doing PhD-studies on land administration infrastructures, partly funded by Aalborg University, Denmark and The Danish National Survey and Cadastre. His thesis is investigating the role of awareness as an evaluation factor for the development potential in cadastral systems towards multi-purpose systems. He graduated with a MSc in Surveying, Planning and Development in 2003, after which he worked $1 \frac{1}{2}$ year in a private surveying company, before staring his $\mathrm{PhD}$-studies in 2005. His current research and interests are SDI, land administration systems and inter-organizational structures.

Abbas Rajabifard is Deputy Director of the Centre for Spatial Data Infrastructures and Land Administration and a Senior Research Fellow in the Department of Geomatics at the University of Melbourne. He holds BSurv (Tehran), Postgrad-Dipl (ITC), MSc (ITC), and has a PhD from the University of Melbourne. He has been an Executive Board member and National representative to Permanent Committee on GIS Infrastructure for Asia and the Pacific 19941999, and member of International Steering Committee for Global Mapping 1997-2001. His current research and interests are spatial data management, SDI development models and SDI capacity building.

Stig Enemark is Professor in Problem Based Learning and Land Management at Aalborg university, Denmark. He is Master of Science in Surveying, Planning and Land Management (1966) and he worked for ten years as a consultant surveyor in private practice. He is currently the President of the Danish Association of Chartered Surveyors. He was Chairman of Commission 2 (Professional Education) of the International Federation of Surveyors (FIG) 1994-98. He is an Honorary Member of FIG and he is Vice-President of FIG 2005-2008. His

TS 62 - SIM - Policy and Strategy

Christian Clausen, Abbas Rajabifard, Stig Enemark and Ian Williamson

Awareness as a Foundation for Developing Efficient Spatial Data Infrastructures

Shaping the Change

XXIII FIG Congress

Munich, Germany, October 8-13, 2006 
teaching and research are concerned with land administration systems, land management and spatial planning, and related educational and capacity building activities.

Ian Williamson's teaching and research cover cadastral, land and geographic information systems, land administration and spatial data infrastructures, in developed and developing countries. He is a Member of the Order of Australia (AM), a Fellow of the Academy of Technological Sciences and Engineering Australia (FTSE), and an Honorary Member of the International Federation of Surveyors (FIG). He was Chairperson of FIG Commission 7 (Cadastre and Land Management) 1994-98 and Director United Nations Liaison for the FIG from 1998- 2002. He is a member of the Executive of the United Nations sponsored Permanent Committee for GIS Infrastructures for Asia and the Pacific (PCGIAP) and Chair of its Working Group 3 (Cadastre). He is Head of the Department of Geomatics and Director of the Centre for Spatial Data Infrastructures and Land Administration, University of Melbourne, Australia.

\section{CONTACTS}

Mr. Christian Clausen

PhD-student

Aalborg University, School of Surveying and Planning

Fibigerstraede 11, 9220 Aalborg, DENMARK

Email: cc@land.aau.dk

Dr. Abbas Rajabifard

Deputy Director, Centre for SDIs and Land Administration

Department of Geomatics, The University of Melbourne

Vic, 3010, AUSTRALIA

Email: abbas.r@unimelb.edu.au

Prof. Stig Enemark

Aalborg University, School of Surveying and Planning

Fibigerstraede 11, 9220 Aalborg, DENMARK

Email: enemark@land.aau.dk

Prof. Ian Williamson

AM, FTSE, Head of the Department of Geomatics and Director of the Centre for Spatial Data Infrastructures and Land Administration

Department of Geomatics, The University of Melbourne

Vic, 3010, AUSTRALIA

Email: ipw@unimelb.edu.au 


\section{University Library}

\section{- M M I N E R VA A gateway to Melbourne's research publications}

Minerva Access is the Institutional Repository of The University of Melbourne

Author/s:

CLAUSEN, CHRISTIAN;RAJABIFARD, ABBAS;ENEMARK, STIG;WILLIAMSON, IAN

Title:

Awareness as a foundation for developing effective spatial data infrastructures

Date:

2006

Citation:

Clausen, C., Rajabifard, A., Enemark, S., \& Williamson, I. (2006). Awareness as a foundation for developing effective spatial data infrastructures, in Proceedings, FIG Congress 2006, Munich, Germany.

Publication Status:

Published

Persistent Link:

http://hdl.handle.net/11343/34926 